\title{
Research Paper \\ Study of the Factors Affecting Academic Dissatisfaction from the Perspective of Teachers, Specialist, and Students
}

\author{
Hilda Haghdoost ${ }^{* 1}$ \\ 1. M.A. in Psychology, Rasht Branch, Islamic Azad University, Rash, Iran
}

Citation: Haghdoost H. Study of the factors affecting academic dissatisfaction from the perspective of teachers, specialist, and students. Quarterly Journal of Child Mental Health. 2019; 6(3): 242-255.

http://dx.doi.org/10.29252/jcmh.6.3.21

\section{A R T I C L E I N F O}

\section{Keywords:}

Academic disturbance, specialists, teachers, students

Received: 8 Apr 2018 Accepted: 26 Jul 2018 Available: 16 Nov 2019

\section{A B S T R A C T}

Background and Purpose: Academic dissatisfaction is one of the most important factors in reducing students' motivation and desire to study. Academic dissatisfaction is influenced by various factors that are important to recognize. The purpose of the present study was to identify important factors in high school students' academic dissatisfaction from perspectives of teachers, specialists, and students. Method: The present study is a survey study in which the perspectives of teachers, specialists, and students are compared. For this purpose, among all teachers of second high school girls in Rasht in 2018, 120 teachers are selected through convenience method; among all psychologists working in educational and research centers in Rasht, 60 are selected through purposeful method; and among all students studying in secondary schools in Rasht, 120 were selected through convenience method. A questionnaire was designed for data collection and its psychometric properties were calculated through exploratory and confirmatory factor analysis.

Results: The results showed that there was a significant difference between the study groups in terms of factors affecting academic dissatisfaction. The results of the data analysis also showed that the most important factors affecting high school students' academic dissatisfaction were: Physical problems and discomfort, lack of information about academic disciplines, lack of qualified teachers, and parenting problems. Comparisons between groups' opinions also indicated a difference between them $(\mathrm{p}<0.001)$.

Conclusion: Considering the problems of students for academic success is very important and for any planning, we must first identify the factors affecting their academic motivation. The results of this study can be helpful in removing students' academic barriers.

\footnotetext{
* Corresponding author: Hilda Haghdoost, M.A. in Psychology, Rasht Branch, Islamic Azad University, Rash, Iran.

E-mail addresses: Hl.haghdoost@gmail.com
}

2476-5740/ (C) 2019 The Authors. This is an open access article under the CC BY-NC-ND license (https://creativecommons.org/licenses/by-nc-nd/3.0/). 


\section{تعيين عوامل مؤثر بر دلزد \\ هيلدا حقدوست \\ ا I. كارشناسى ارشد روانشناسى، واحد رشت، دانشكاه آزاد اسلامى، رشت، ايران}

جكيده

زمينه و هدف: دلزدگى تحصيلى از مهم ترين عوامل در كاهش انظيزه و تمايل دانش آموزان براى تحصيل است. دلزدگى از ادامه تحصيل

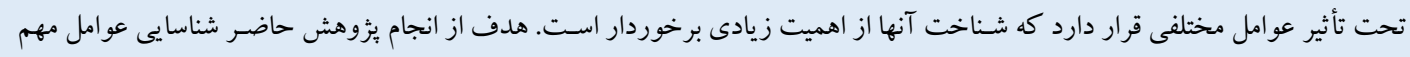

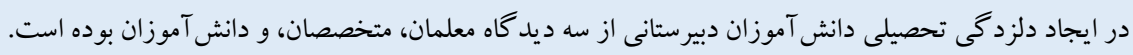

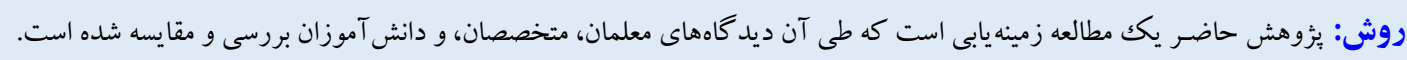

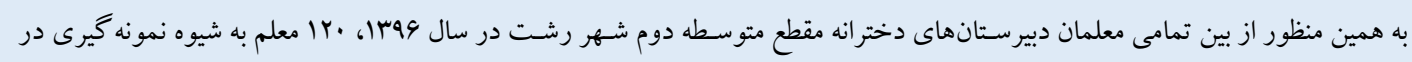

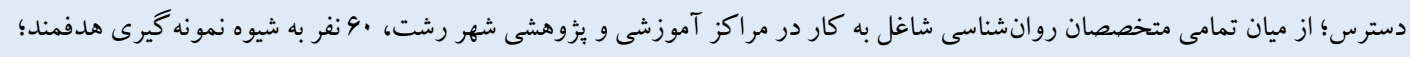

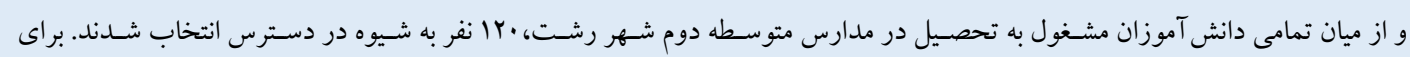
جمع آورى دادهها يرسشنامهاى طر احى و شاخص هاى روانسنجى آن از طريق تحليل عاملى اكتشافى و تأييدى محاسبه شد.

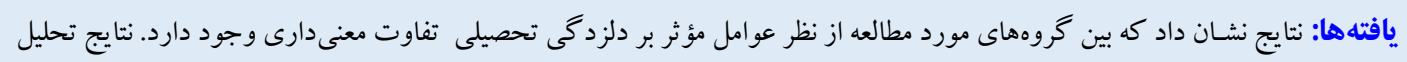

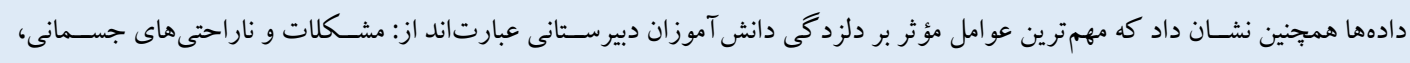

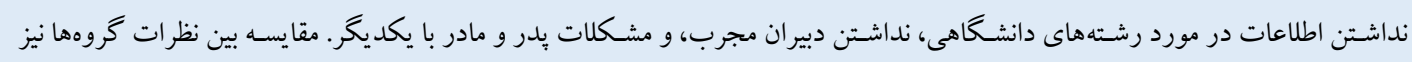

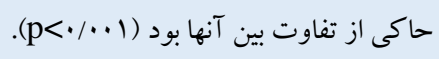

نتيجه كيرى: توجه به مشـكلات دانش آموزان براى موفقيت تحصـيلى از اهميت فراوانى برخوردار اسـت و براى هر گونه اقدامى ابتدا بايد

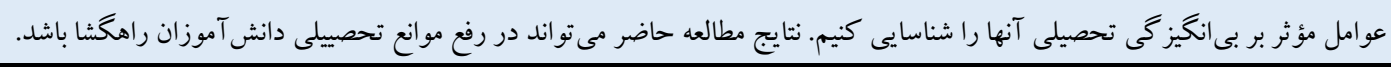

مشخصات مقاله

$$
\begin{aligned}
& \text { كليدوازهها: } \\
& \text { دلزدگى تحصيلى، }
\end{aligned}
$$

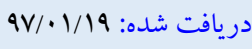
و منتشر شده:

* نويسنده مسئول: هيلدا حقدوست، كارشناسى ارشد روانشناسى، واحد رشت، دانشكاه آزاد اسلامى، رشت، ايران.

رايانامه: H1.haghdoost@gmail.com

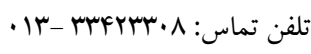


شـخصى اش شـود و كاهش خود كار آمدى سـبب كاهش اعتماد به خود شــده كه در نتيجه اين سـه عامل در كنار هم، در نارضـايتى و شـكست تحصيلى مى توانند تأثير زيادى داشته باشند (A).

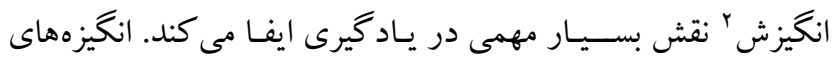
مثبت و منفى مى تو انند عملكردهاى علمى و روانى فرد را تحت تأثير قرار دهند (9-11). بسـيارى از مربيان و متخصـصــان نظام آموزشسى تقويت

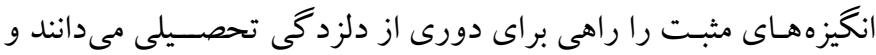
يكى از مهم ترين عوامل فرسودگى تحصيلى را نااميدى فرد و انكيزههاى منفى او مى داننـد (Y I). ليندون و همكاران در بزّوهش خود به اين نتيجه رسـيدند كه دلزدگى و كيفيت زندگى دانشسويان بزشـكى با تفاوت در انخًزه و موفقيت تحصسيلى در طول زمان ارتباط دارد (سا). فرسـودكى تحصـيلى مى تواند منجر به عدم مشـاركت و كاهش انرزى لازم براى

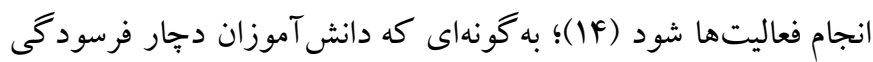
تحصـيلى، انكيزهاى براى شـر كت در فعاليتهاى كلاسـى ندارند و ويز گیىهاى رفتارى مانند غايب شـدن، تأخير در حضسور در كلاس، و تر كك زودهنگام كلاس را از خود نشان مىدهند. بهعلاوه آنها در كلاس بـه مطـالب درسـى كوش نداده و در فعاليتهاى گروهى شــركت نمى كنند.همجينين اين دانش آموزان اغلب براى كلاس و معلم احترامى قائل نبوده، وبراى عملكرد ضـعيف تحصسيلى خود بهانه تراشى مى كنند؛ بنابراين حس مسـئوليت يذيرى و ياسـخ گويى در برابر عملكرد ضسعيف خود در اين افراد وجود ندارد (ها). با توجه به بيامدهاى منفى دلزدگى، متخصـصـان تعليم و تربيت، بررسى و شناسايى علل دلزدگى تحصيلى را در دستور كار قرار دادهاند. (F). ئفريولى و همكساران، در يثزوهش خود كه با هدف بررسـى اثرات مســتقيم و غيرمسـتقيم فرســودگى تحصــيلى، تعامل و افســردگى در دانش آموزان بـا كنترل عـامـل سـن و جنس، بر روى · إ دانش آموز ايتاليايى در مغطع دبيرستان انجام دادند به اين نتيجه رسيدند كه فرسودكى دانش آموزان، اثرات قوى بر موفقيت تحصسيلى آنها دارد كه اثرات منفى آن بهطور مستقيم و غيرمستقيم با علائم افسردگى و مشار كت در مدرسه ارتباط دارد (19). كانوس در مطالعه خود با عنوان فرســودگى مرتبط با مـدرســه و راهكـارهاى مقابله دانش آموزان به اين نتيجه رســيد كه اين
زندگى تحصيلى، يكى از مهمترين ابعاد زندگى اشـخاص است كه بر

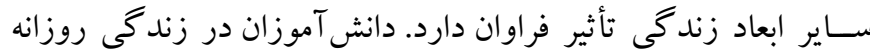

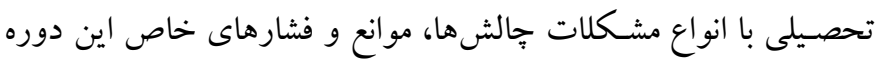

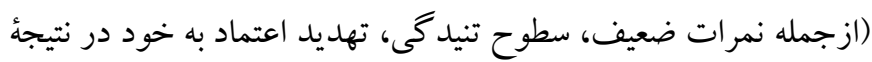

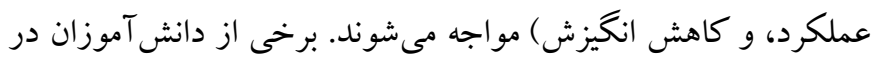

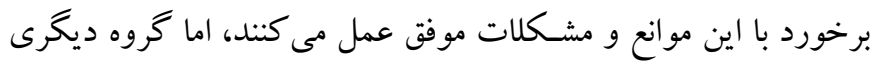
از دانش آموزان در اين زمينه ناموفق هستند (1). در مدرسه، تعامل معمولاً

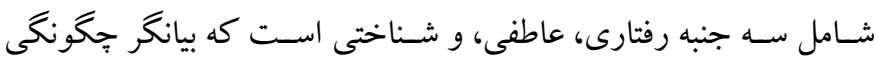

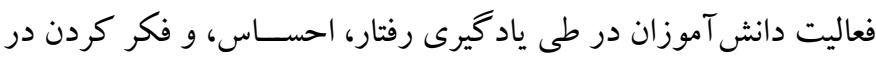

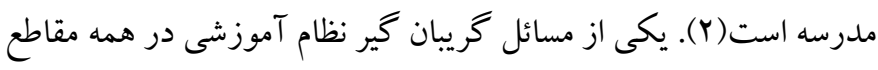
تحصيلى كه موجب هدر رفتن نيروى انسانى و هزينهاى بسيار مى شوده،

$$
\text { فرسودىى تحصيلى' است (r). }
$$

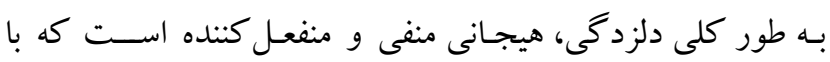

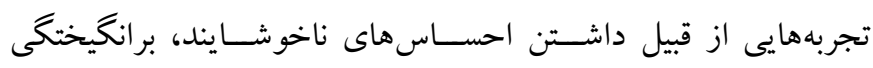

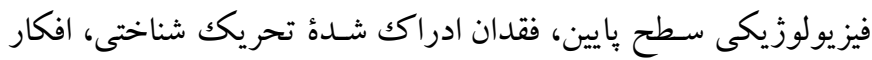
نامرتبط با تكليف (براى مثال خياليردازى)، به طول انجاميدن ذهنى

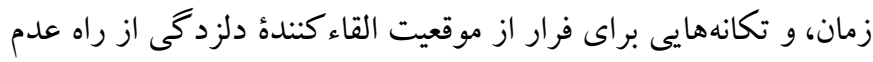

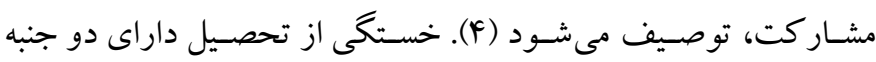

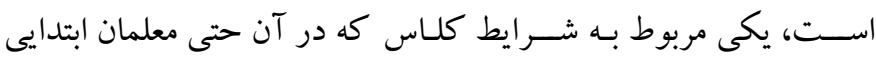

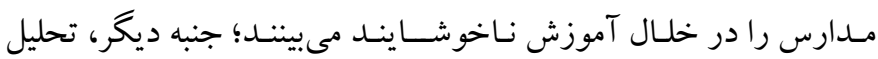

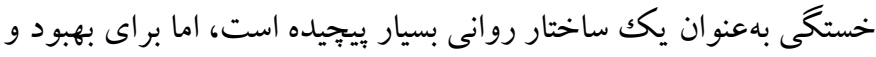

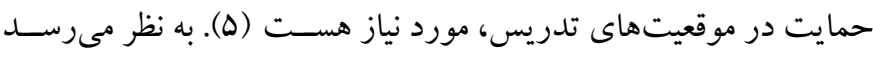

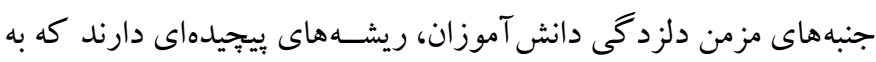

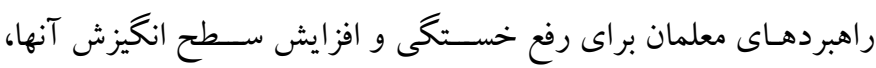
بستخى دارد (4). احسـاس خستخى در مدرسه، لذت نبردن از مدرسه، و ارزش قائل فئل

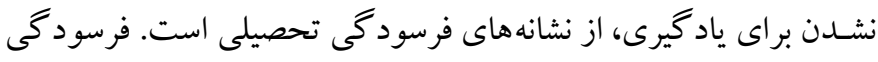

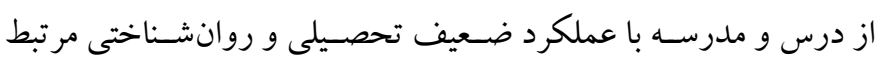

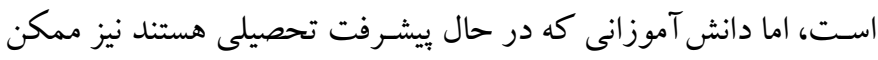

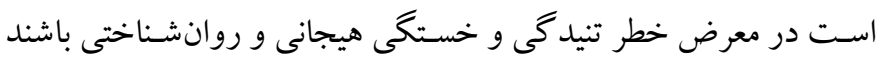

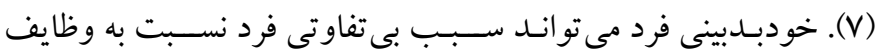

1. Academic burnout 
روش الف) طرح يزوهش و شر كت كنند كان: هدف از انجام يزوهش حاضر

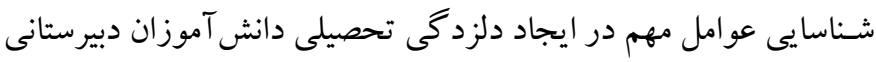

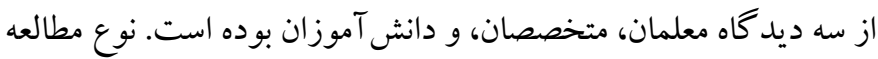
در بزوهش حاضر از نوع زمينه يابى است كه طى آن ديد گاههاى معلمان، متخصصان، و دانش آموزان درباره دلزد گحى تحصيلى دانش آموزان مقطع

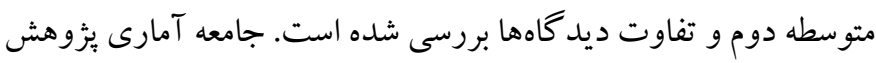
حاضـر شامل تمامى معلمان مقطع متوسطه دوم دولتى دختر انه شهر رشت در سـال تحصيلى وهوا، تمامى متخصصان روانشناسى و تعليم و تربيت

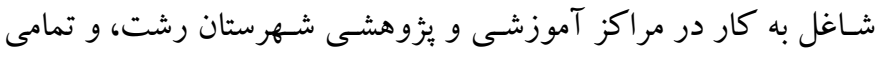

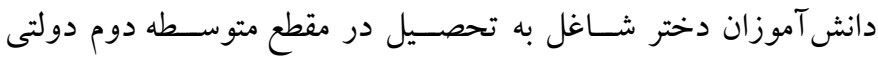

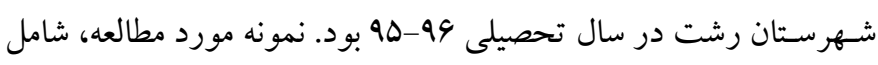

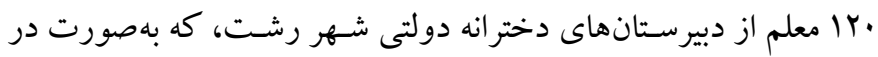
دسترس انتخاب شدند. معلمان انتخاب شده دبيران با تجربه و كار آمدى دهى دهري

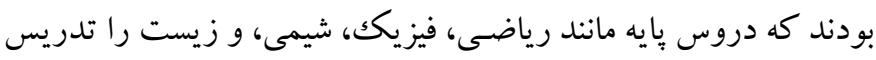

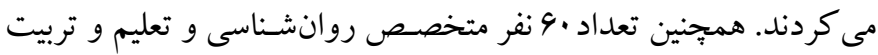

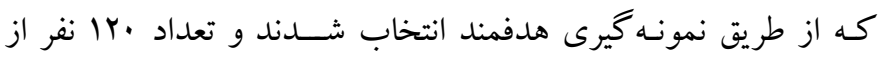
دانش آموزان دختر مقطع متوسطه دوم دخترانه شهر رشت كه به شيه شيوه در

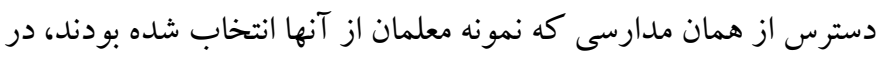
صـورت داشــن رضـايت براى شـر كت در ثيزوهش مورد مطالعه قرار كرفتند. شـرايط ورود به يُزوهش عبارت بودند از: سن دانش آموز (ها تا

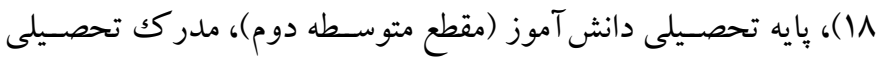
متخصصان (حداقل كارشناسى ارشد روانشناسى و علوم تربيتى)، ميزان

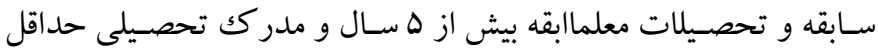
كارشناسى)

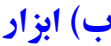

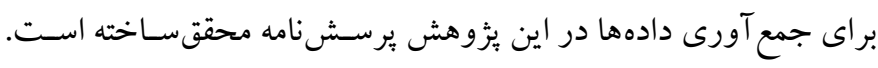
براى ساخت اين برسشنامه مراحل زير استفاده شده است:

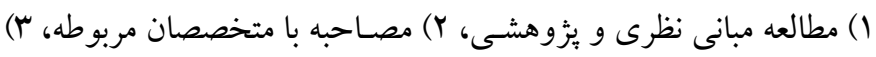

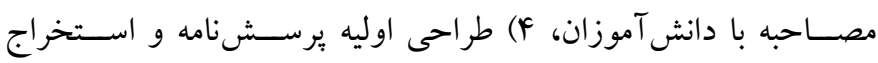

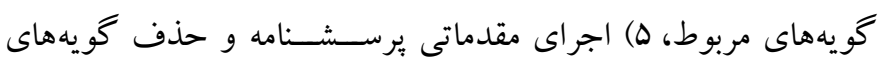
نامربوط، و 9) اجر ایى نهايى برسشنامه و تحليل عاملى.
مشـكل با تمام نشـانههايى مانند خستخّى از خواسـته هاى مدرسه، بدبينى نسبت به كار مدرسه، و احساس ناكار آمد بودن در مدرسه ديده مى شود

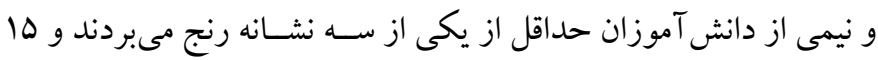

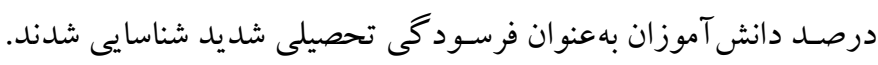

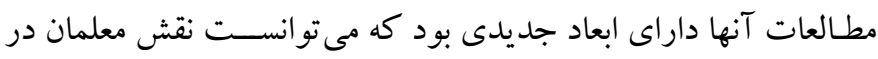
ييشخيرى و درمان فرسود گكى دانش آموزان را تأييد كند اما آنها دريافتند

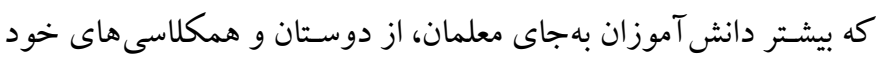

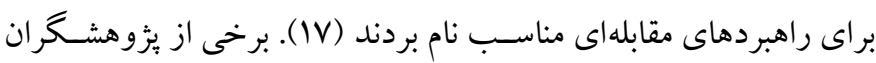

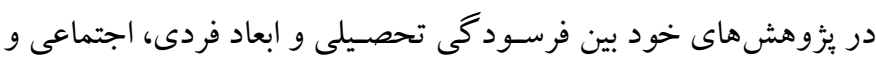

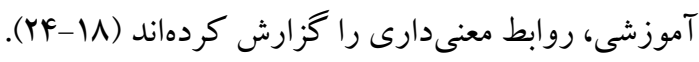

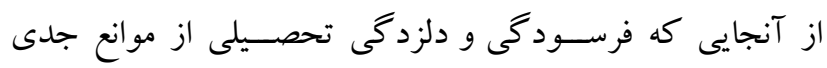

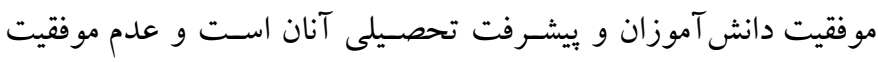

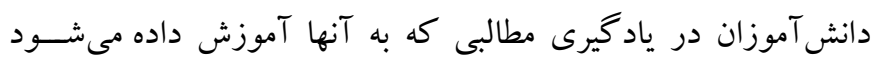

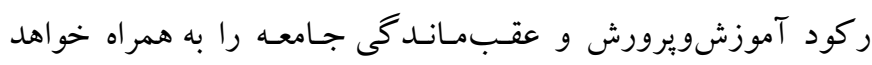

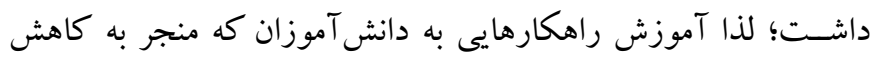
فرسودگى تحصيلى در آنان شود، بسيار ضرورى است. جنبه نو آورانه در

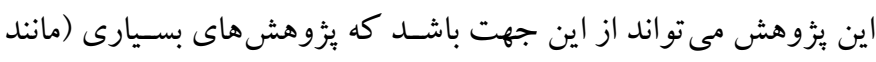

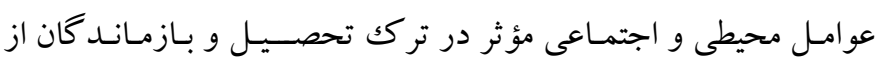

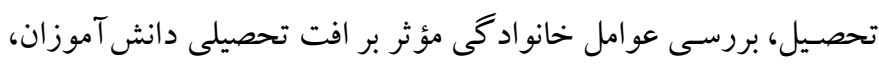
رابطه بين فرسودگى تحصيلى با اشتياق و عملكرد تحصيلى، و نظاير آن)

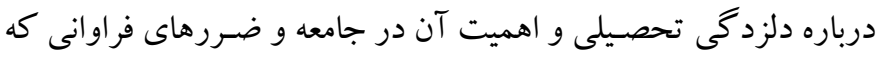

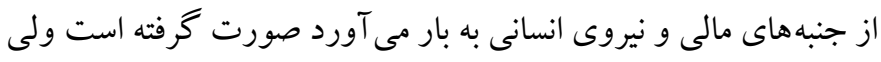

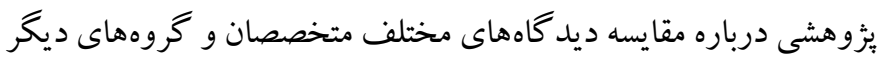

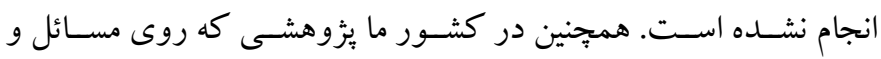

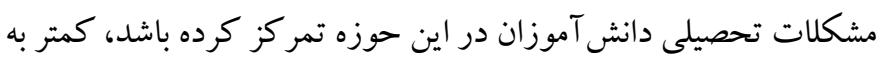

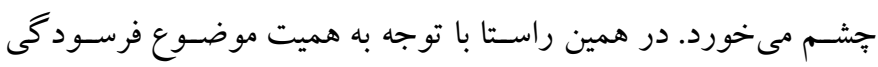

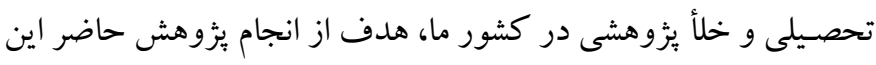

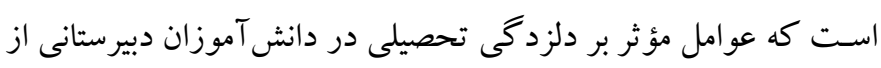

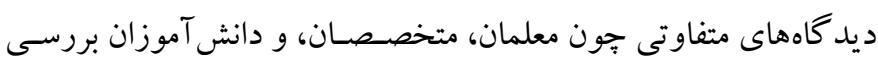


ابزار مورد استفاده در يزوهش، ديد گاههاى آنها بررسى شد. براى بررسى

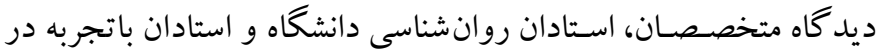
تعليم و تربيت و مشـاوره، تحصيلى انتخاب شدند و يرسشنامه مورد نظر

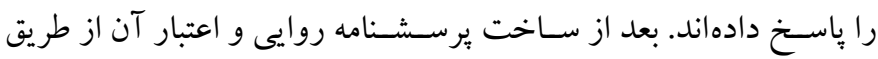
تحليل عاملى تأيدى و اكتشـافى و ضـريب آلفاى كرونباخ محاسبه شد.

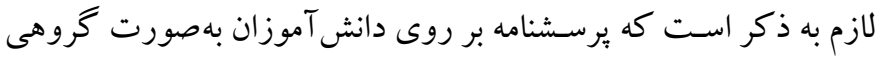

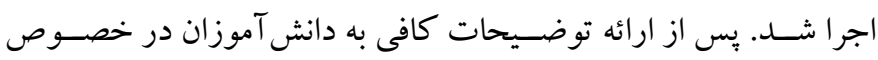

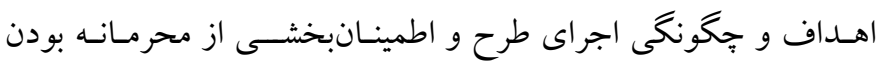
اطلاعات، افرادى كه تمايل به شـركت در طرح داشتند رضايتنامه كتبى وركي

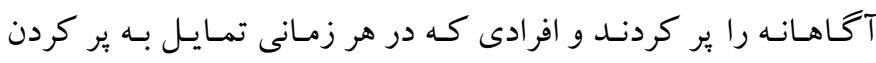
يرسشنامه نداشتند مى تو انستند از مطالعه خارج شوند. در پايان براى تحليل دادههاى جمع آورى شده از آزمون فريدمن استفاده شد...

\section{يافتهها}

در اين بخش يافتهاى يُزوهش در قالب باسخ به سؤ الهاى يثزوهش ارائه

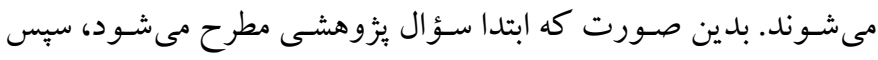

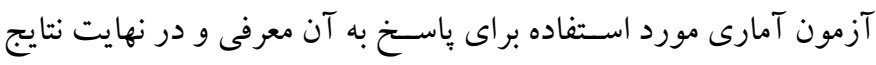

$$
\text { آن آزمون در قالب جدول و توضيحات ارائه مى شود. }
$$

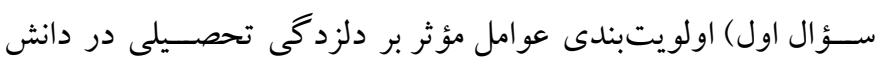

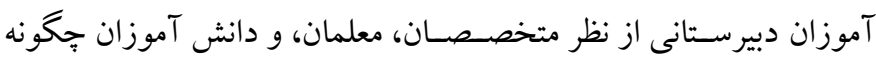

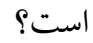

براى اولويتبندى عوامل مؤثر بر دلزدگى تحصـيلى در دانش آموزان

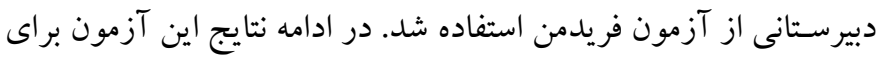

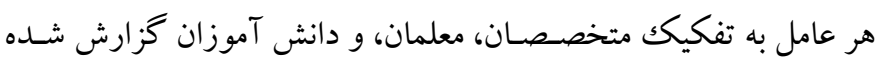

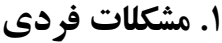

در جدول انتايج آزمون فريدمن براى اولويتبندى گويههاى مربوط به

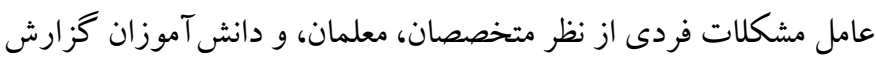

يرسـش نامه نهايى تدوين شـده داراى بَز گويه بوده اسـت كه بر اسـاس

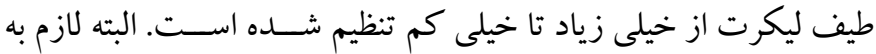

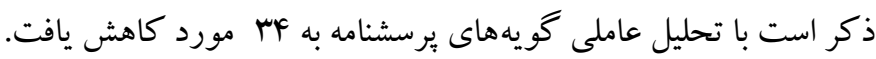
جهت تأييد روايى محتو ايى برسـش نامه از نظر و قضـاوت اسـتادان علوم

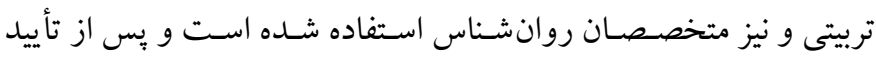

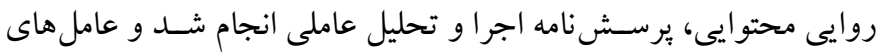
فردى، اجتماعى، و آموزشى استخر اج شد. يايايى يرسشنامه نيز از طريق برسي

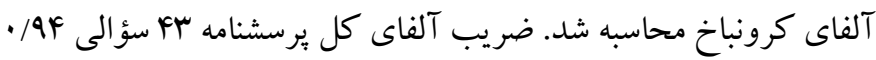

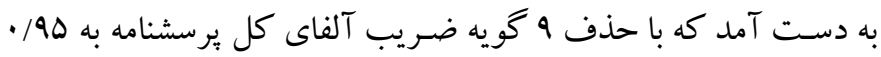
افزايش بيـدا كرد. در فرايند تحليل عاملى اكتشـافى، آزمون KMO و آزمون كرويت بارتلت انجام شـد. ضريب به دست آمده

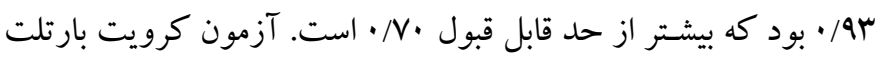

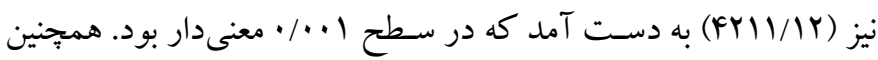

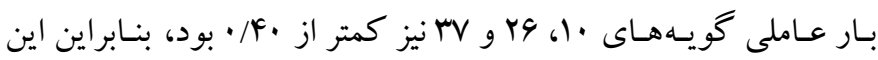

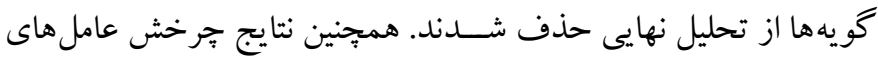

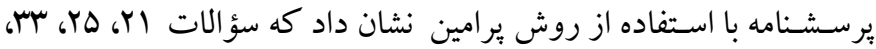

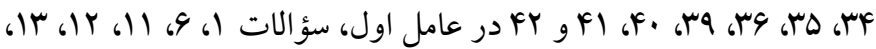

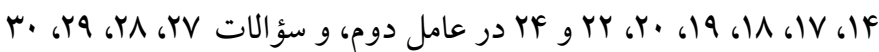
و الب در عامل سوم بار عاملى معنىدار دارند. للازم به ذكر است كه تمامى

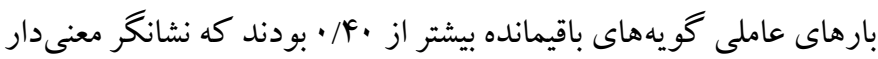

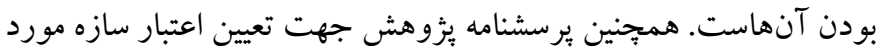

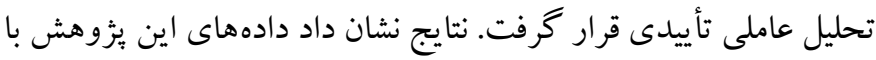
ساختار عاملى اين برسشنامه برازش مناسبى دارد و عامل ها تأييد شدند. ج) روش اجرا: براى اجراى يزوهش حاضر يس از كسب مجوز از اداره

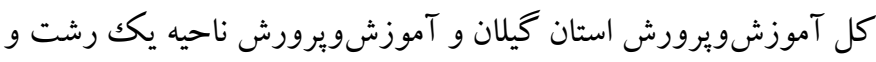

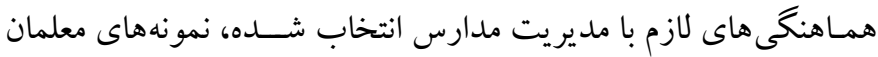

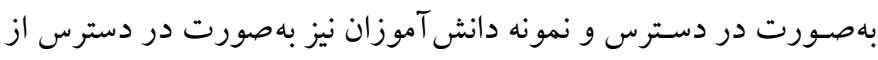

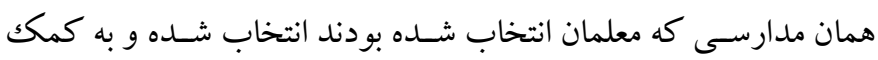


جدول ا: نتايج آزمون فريدمن مربوط به كويه هاى عامل مشكلات فردى از نظر متخصصان، معلمان، و دانش آموزان

\begin{tabular}{|c|c|c|}
\hline رتبه & ميانگين رتبه & متخصصان/گويه \\
\hline & & 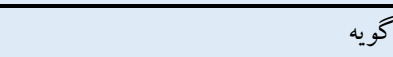 \\
\hline 1 & $9 / V Y$ & مشكلات و ناراحتىهاى جسمانى \\
\hline r & $\Delta / a r$ & مشكلات يدر و مادر دانش آموز با يكديخر \\
\hline$r$ & $\Delta / \wedge F$ & مشكلات هيجانى رفتارى \\
\hline & & آماره آزمون (آزمون فريدمن) \\
\hline سطح معنىدارى & درجه آزادى & آماره خى دو \\
\hline$\cdot / \cdot 1$ & 9 & $r V / 99$ \\
\hline رتبه & ميانكين رتبه & معلمان/Fويه \\
\hline 1 & $9 / 10$ & مشكلات و ناراحتىهاى جسمانى \\
\hline r & $\Delta / A r$ & مشكلات هيجانى رفتارى \\
\hline$r$ & $\Delta / V \Delta$ & مشكلات مربوط به كسب هويت \\
\hline & & آماره آزمون (آزمون فريدمن) \\
\hline 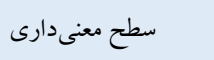 & درجه آزادى & آماره خى دو \\
\hline$\% \Delta$ & 9 & $r r / \& V$ \\
\hline رتبه & ميانكين رتبه & دانش/آموزان/كويه \\
\hline 1 & G/VY & مشكلات و ناراحتى هاى جسمانى \\
\hline r & $\Delta / ৭ r$ & مشكلات يدر و مادر دانش آموز با يكديخر \\
\hline r & $\Delta / \wedge F$ & مشكلات هيجانى رفتارى م \\
\hline & & آماره آزمون (آزمون فريدمن) \\
\hline سطح معنى دارى & درجه آزادى & آماره خى دو \\
\hline$\cdot / \cdot \cdot 1$ & 9 & $r V / 99$ \\
\hline
\end{tabular}

فردى بر ديخر ميـانخين رتبـهــا ارجحيـت دارد. مشــكلـات يدر و مادر

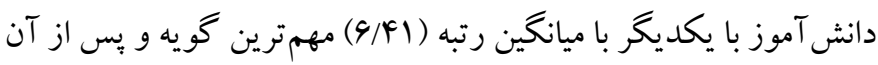

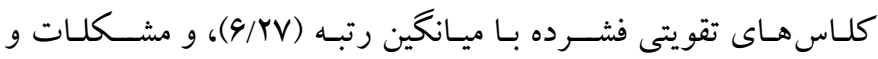

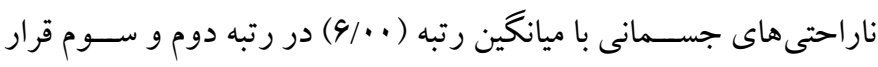
دارند.

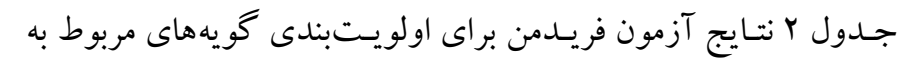

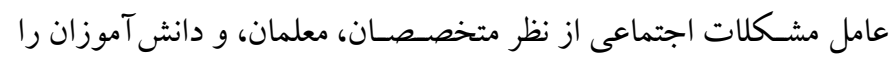
نشان مىدهد.
بـا توجـه بـهـ جدول 1، در رابطه با نظر متخصــصــان، مشـكلات و

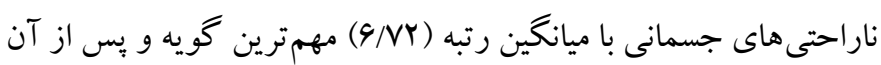

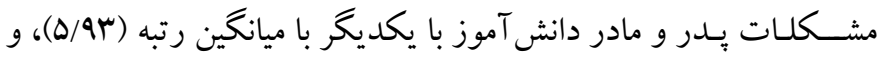
مشكلات هيجانى رفتارى با ميانخين رتبه (ه/AF) در رتبه دوم و سوم قرار

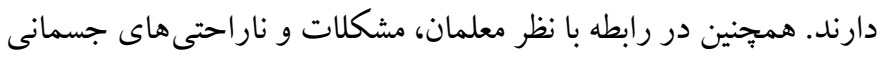

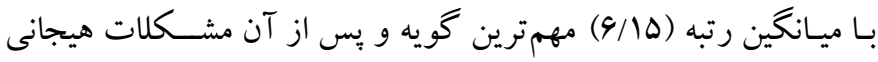

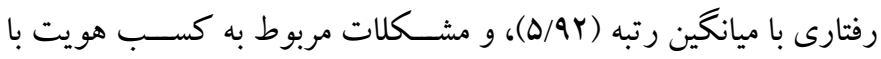

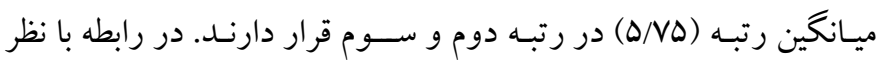

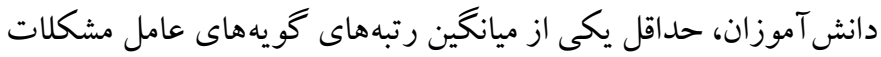


جدول ب: نتايج آزمون فريدمن مربوط به تويههاى عامل مشكلات اجتماعى از نظر متخصصان، معلمان و دانشآموزان

\begin{tabular}{|c|c|c|}
\hline 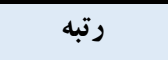 & ميانكين رتبه & متخصصان/كويه \\
\hline 1 & V/FT & دشوارى صرف نظر كردن از لذتها و تفريحات \\
\hline r & $V / r$. & نداشتن اطلاعات دقيق در مورد رشتههاى دانشكاهى \\
\hline \multirow[t]{2}{*}{$r$} & $V / \cdot r$ & كثرت دانشكاهها و قبولى اكثريت در دانشكاه \\
\hline & & Tماره آزمون (آزمون فريدمن) \\
\hline سطح معنى دارى & درجه آزادى & آماره خى دو \\
\hline.$/ \cdot 1$ & 11 & $r r / 9$. \\
\hline 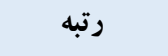 & ميانكين رتبه & معلمان/Fويه \\
\hline 1 & $V / r$. & نداشتن اطلاعات دقيق در مورد رشتههاى دانشخاهى \\
\hline r & $V / I f$ & بى كيفيت بودن سطح دانشكاهها \\
\hline$r$ & 9/9 & كمال كرايى والدين نسبت به دانش آموز \\
\hline & & آماره آزمون (آزمون فريدمن) \\
\hline سطح معنى دارى & 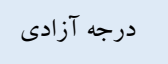 & 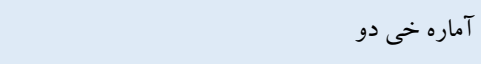 \\
\hline$\% \cdot \cdot 1$ & 11 & $\kappa q / \mu q$ \\
\hline رتبه & ميانكين رتبه & دانش آموزان/كويه \\
\hline 1 & $V / F T$ & كثرت دانشكاهها و قبولى اكثريت در دانشكاه \\
\hline r & $V / r q$ & كاربردى نبودن محتواى كتابها \\
\hline$r$ & $v / r$ & آماره آزمون (آزمون فريت دانشمن) \\
\hline سطح معنى دارى & درجه آزادى & Tماره خیى دو \\
\hline$\cdot / . .1$ & 11 & $\Lambda r / 91$ \\
\hline
\end{tabular}

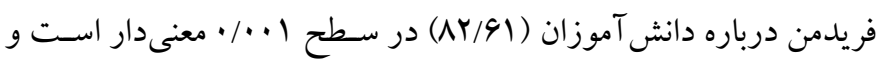

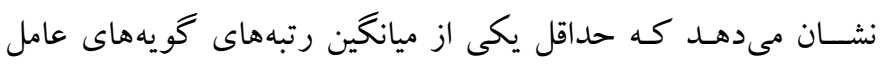

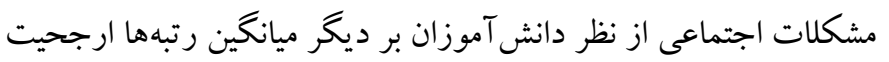

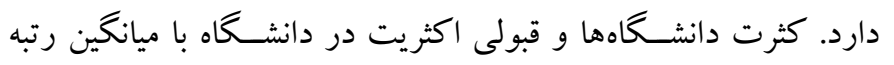
(V/Fr)

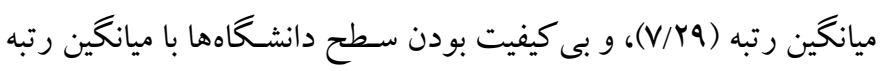
(V/Tr) r. مشكلات آموزشى

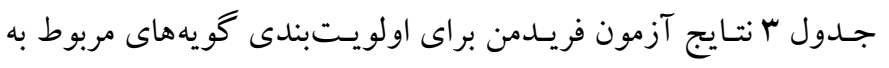

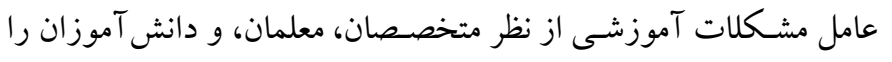
نشان مىدهد.
با توجه به جدول Y نتايج آزمون فريدمن درباره متخصصان ( • (Y (Y/Q)

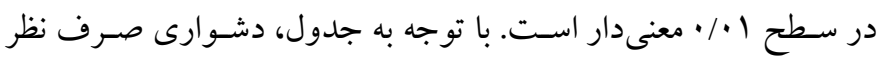

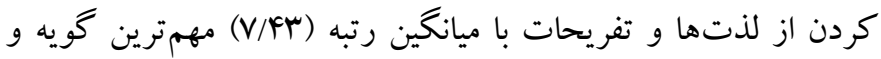
يس از آن نداشتن اطلاعات دقيق در مورد رشتهاى دانشكاهى بـ با ميانگين

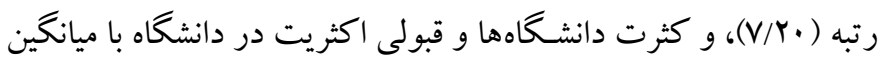

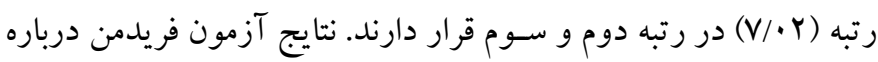

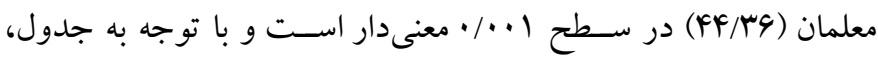

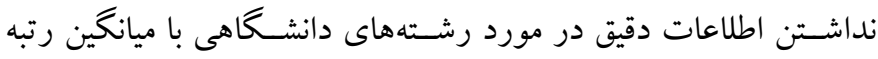

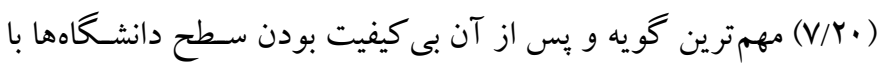

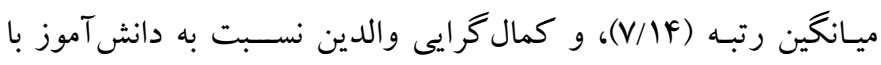

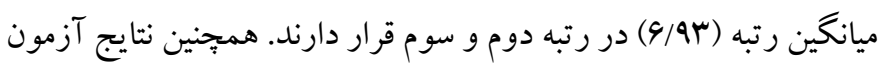


جدول r: نتايج آزمون فريدمن مربوط به كويههاى عامل مشكلات آموزشى از نظر متخصصان، معلمان و دانش آموزان

\begin{tabular}{|c|c|c|}
\hline رتبه & ميانكين رتبه & متخصصان/كويه \\
\hline 1 & $r / r q$ & نداشتن دبيران مجرب در مدرسه \\
\hline r & $r / \cdot F$ & بى انخيز گى دييران \\
\hline \multirow[t]{2}{*}{$r$} & $r / 9 r$ & نداشتن مشاور خوب در مدرسه \\
\hline & & آماره آزمون (آزمون فريدمن) \\
\hline سطح معنى دارى & درجه آزادى & آماره خى دو \\
\hline .1 .4 & r & N/q. \\
\hline 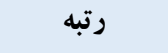 & ميانغين رتبه & معلمان/كويه \\
\hline 1 & r/rq & بهروز نبودن دبيران \\
\hline r & $r / r$. & نداشتن دبيران مجرب در مدرسه \\
\hline \multirow[t]{2}{*}{ r } & $r / \cdot v$ & بىانكيز كى دييران \\
\hline & & آماره آزمون (آزمون فريدمن) \\
\hline سطح معنى دارى & درجه آزادى & آماره خى دو \\
\hline.$/ .1$ & $r$ & $r r / A 1$ \\
\hline رتبه & ميانكين رتبه & دانشآموزان/كويه \\
\hline 1 & $r / I r$ & بى انغيز كى دييران \\
\hline$r$ & $r / . r$ & نداشتن دبيران مجرب در مدرسه \\
\hline \multirow[t]{2}{*}{$r$} & $r$ & نداشتن مشاور خوب در مدرسه \\
\hline & & آماره آزمون (آزمون فريدمن) \\
\hline سطح معنى دارى & درجه آزادى & آماره خى دو \\
\hline.$/ 91$ & $r$ & $r / r q$ \\
\hline
\end{tabular}

نتايج آزمون فريدمن در رابطه با دانش آموزان نيز (Y/rq) معنىدار نيست

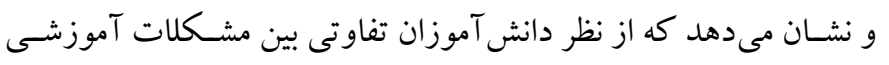

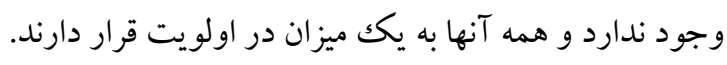

\section{ع. كل بر سشنامه}

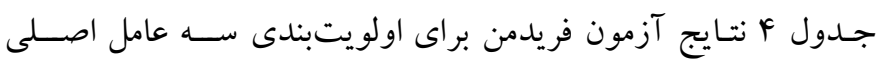

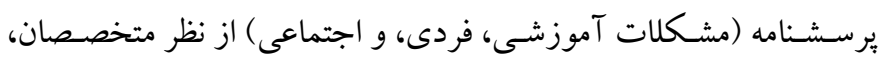
معلمان، و دانش آموزان را نشان مىدهد.

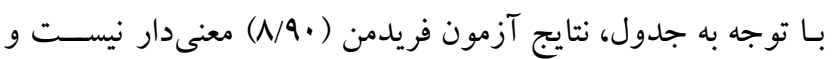

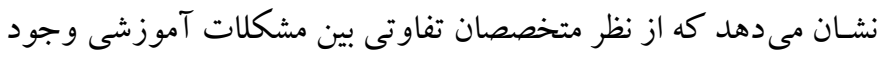

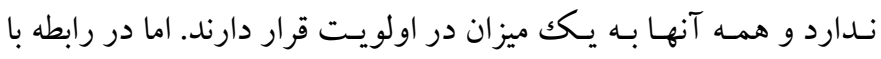

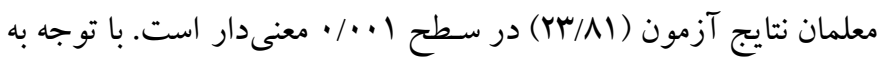

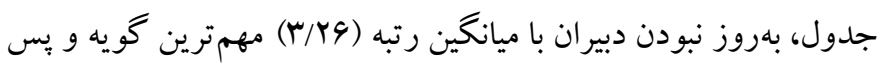

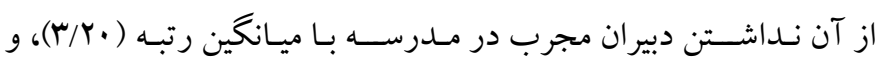

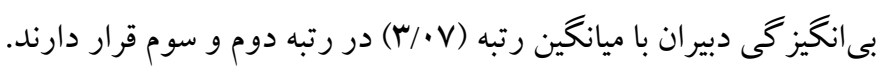

جدول ع: نتايج آزمون فريدمن مربوط به سه عامل يرسشنامه از نظر معلمان و دانش آموزان

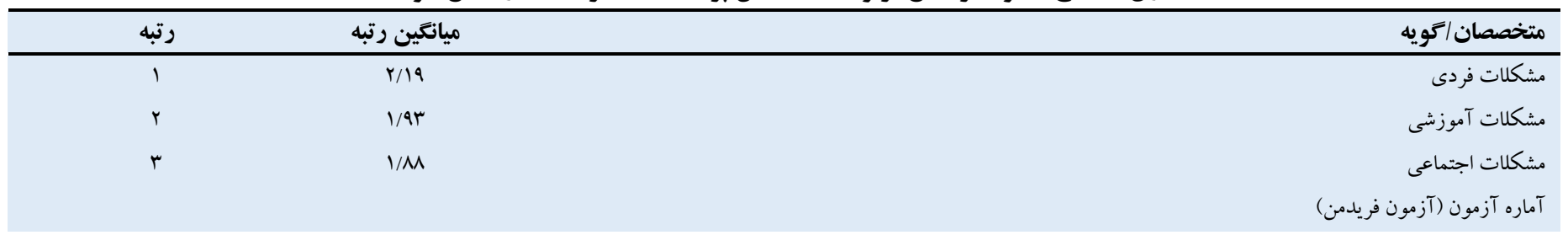




\begin{tabular}{|c|c|c|}
\hline سطح معنى دارى & درجه آزادى & 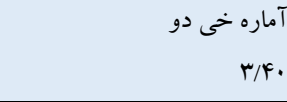 \\
\hline رتبه & ميانغين رتبه & معلمان/گويه \\
\hline 1 & $Y / I V$ & مشكلات آموزشى \\
\hline r & $r / . q$ & مشكلات فردى \\
\hline$r$ & $1 / V F$ & مشكلات اجتماعى \\
\hline & & آماره آزمون (آزمون فريدمن) \\
\hline سطح معنى دارى & درجه آزادى & آماره خى دو \\
\hline$\% r$ & r & $1 Y / \Delta \Lambda$ \\
\hline رتبه & ميانكين رتبه & دانش/آموزان/كويه \\
\hline 1 & $r / Y r$ & مشكلات فردى \\
\hline r & $r / r$. & مشكلات آموزشى \\
\hline \multirow[t]{2}{*}{$r$} & $1 / \Delta \wedge$ & مشكلات اجتماعى \\
\hline & & آماره آزمون (آزمون فريدمن) \\
\hline سطح معنى دارى & درجه آزادى & آماره خى دو \\
\hline$\cdot / \cdot 1$ & r & rI/Or \\
\hline
\end{tabular}

واريانس جندمتغيرى يككر اهه اسـتفاده شــــ. براى بررسـى نرمال بودن

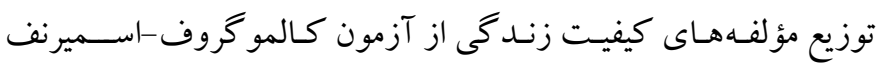

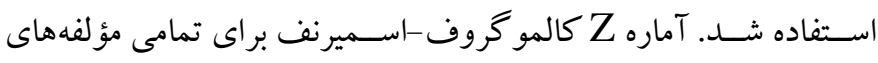

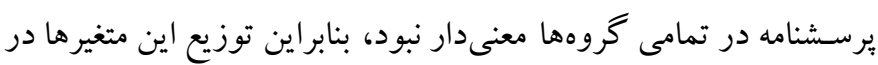

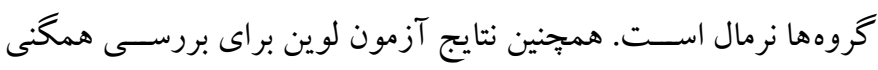

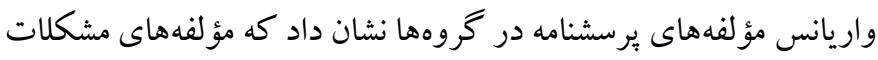

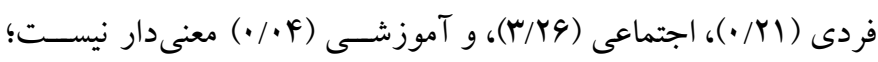

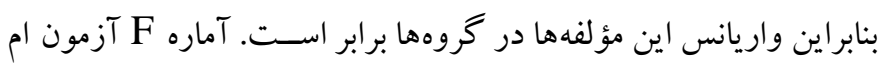

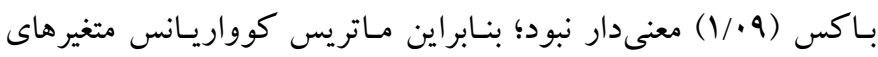

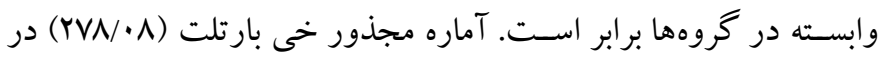

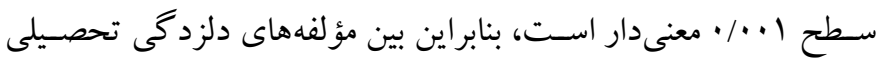

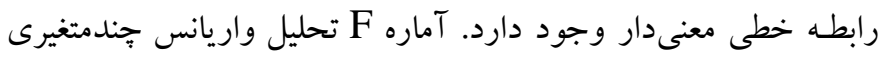

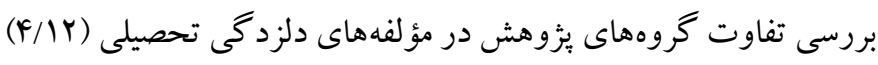

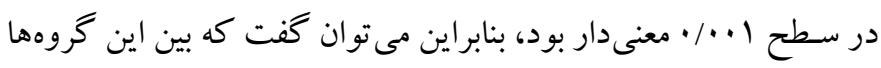

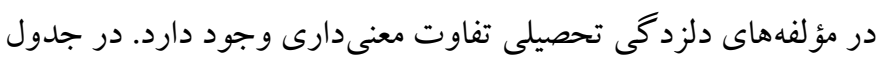
ه نتايج تحليل واريانس يككراهه گزارش شده است.
با توجه به جدول F آماره آزمون فريدمن متخصصان (•F/F) معنىدار

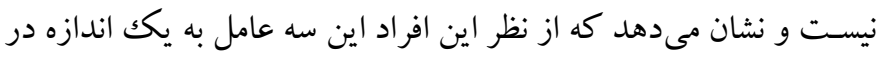

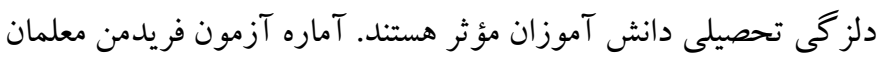

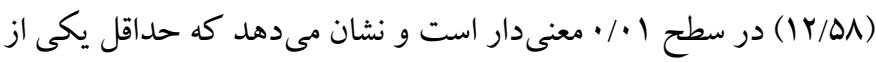
ميانخين رتبه هاى سـه عامل برســــــامه از نظر معلمان بر ديخر ميانخين رتبه ها ارجحيت دارد. مشكلات آموزشى با ميانگين رتبه (Y//VV) مهم ترين

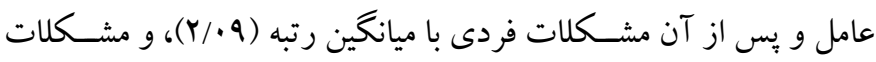
اجتماعى با ميانگين رتبه (1/VF) در رتبه دوم و سـوم قرار دارند. همجينين

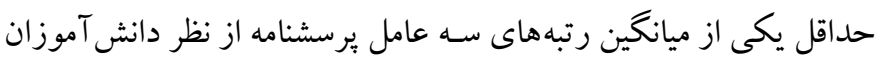

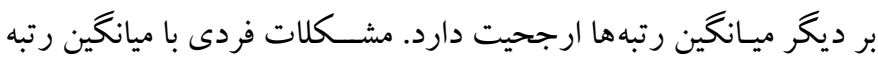

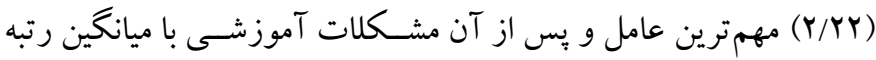

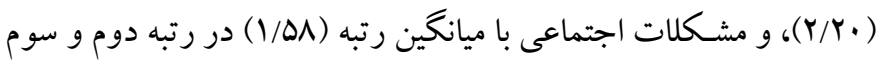

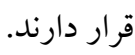
سوال دوم) آيا بين متخصـصـان، معلمان و دانش آموزان در مؤلفههاى

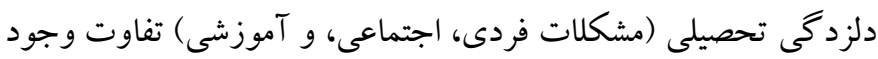
دارد؟ براى بررسى تفاوت متخصـصـان، معلمان، و دانش آموزان در مؤلفههاى دلزدگى تحصـيلى (مشـكلات فردى، اجتماعى، و آموزشـى) از تحليل 
جدول 0: نتايج تحليل واريانس يكرراهل تفاوت تروهها در مؤلفههاى دلزدكى تحصيلى

\begin{tabular}{|c|c|c|c|c|c|c|c|}
\hline مجذور اتا & $\mathbf{p}$ & $\mathbf{F}$ & خطا MS & كروه MS & خطا SS & Sروه SS & مؤلفه \\
\hline .1 .9 &.$/ .1$ & $9 / \wedge \Delta$ &.$/ 9$. & $\Lambda / M$ & $r 9 V / 91$ & $\mathrm{IV} / \mathrm{W}$ & مشكلات فردى \\
\hline$\cdot / \cdot r$ &.$/ r$ & r/vi & .194 & $r / \Delta$. & $199 / \mu F$ & $\Delta$ & مشكلات اجتماعى \\
\hline .1 .0 &.$/ .1$ & $\Lambda / 1$. & $1 / 10$ & $Q / \mu F$ & TFY/DV & $11 / 99$ & مشكلات آموزشى \\
\hline
\end{tabular}

تفـاوت معنى دارى وجود دارد. در جــول 9 نيز نتـايج مقـايسـه زوجى كروهها در اين مؤلفهها نشان داده شده است.
با توجه به جدول ه آماره F براى مؤلفههاى مشكلات فردى (ه/Aه)،

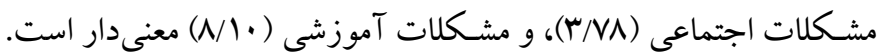

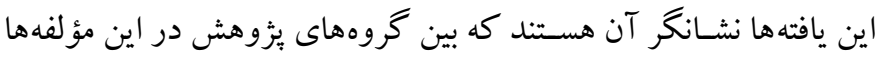

جدول ح: نتايج مقايسه زوجى كروهها در مؤلفههاى دلزدكى تحصيلى

\begin{tabular}{|c|c|c|c|c|c|}
\hline سطح معنىدارى & خطاى استاندارد & تفاوت ميانتين & كروه & كروه & متغير \\
\hline$\cdot / \pi \Delta$ &.$/ 10$ & $-\cdot / I V$ & معلمان & متخصصان & \\
\hline$\% \cdot 1$ & .110 & $-\cdot / 09$ & دانش آموزان & متخصصان & مشكلات فردى \\
\hline.$/ \cdot 1$ & $\cdot / 1 r$ & $-\cdot / A r$ & دانش آموزان & معلمان & \\
\hline 每/ & $\cdot / r$ & $-\cdot / T$ & معلمان & متخصصان & \\
\hline.$/ .1$ &.$/ 1 r$ & r & دانش آموزان & متخصصان & مشكلات اجتماعى \\
\hline .1 .9 &.$/$ & $\cdot / r$. & دانش آموزان & معلمان & \\
\hline.$/ \cdot 1$ &.$/ 1 \mathrm{~V}$ & $-\cdot|4|$ & معلمان & متخصصان & \\
\hline$\% \cdot 1$ &.$/ \mathrm{VV}$ & -.191 & دانش آموزان & متخصصان & مشكلات آموزشى \\
\hline .1 .9 & - 每 & $-\cdot / 14$ & دانش آموزان & معلمان & \\
\hline
\end{tabular}

ديـــــاه معلمـان بــه ترتيـب عبـارت بودند از: مشــكلات و ناراحتى هاى جسـمانى، نداشـتن اطلاعات دقيق در مورد رشتههاى دانشكاهى، و بهروز نبودن دبير ان. همجنين نتايج تحليـل دادهـا با اســفاده از آزمون تحليل

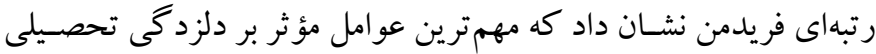

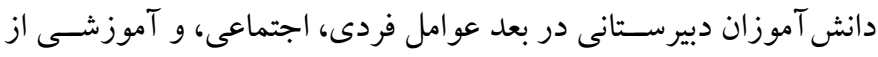

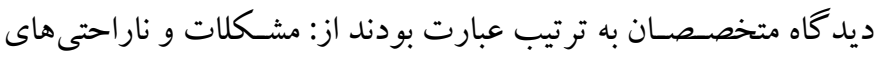
جسـمانى، دشـوارى صـرف نظر كردن از لذتها و تفريحات، و نداشـن دبيران مجرب در مدرسه. از ديد گاه دانش آموزان، مهم ترين عوامل مؤثر

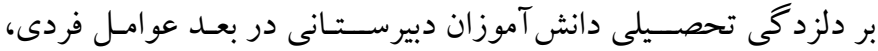

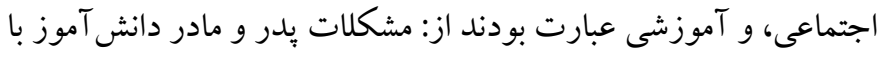

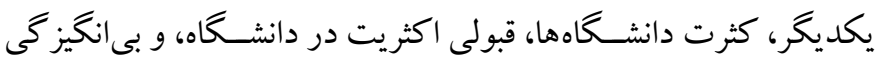

$$
\text { دبيران. }
$$

يـافتـهــاى حـاصـل از اين بخش از يزوهش بـا نتـايج يزوهش هاى

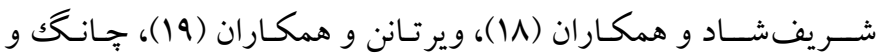

با توجه به جدول 9 بين ميانگين متخصصـان، و معلمان در مشككلات

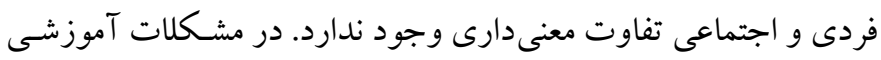
نيز ميانگين معلمان بهصـورت معنى دارى بيشـتر از ميانگين متخصـصــان

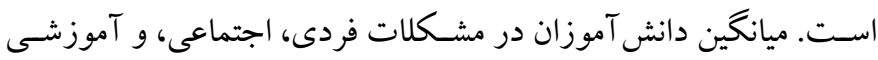

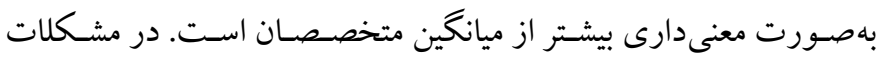

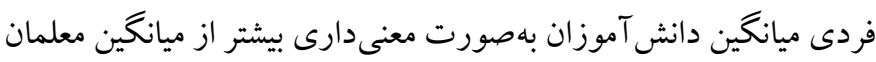
است، اما در مشكلات اجتماعى و آموزشى تفاوت معنى دارى بين ميانخين

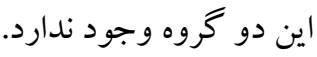

\section{بحث و نتيجه تيرى}

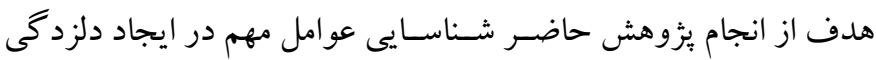
تحصيلى دانش آموزان دبيرستانى از سـه ديد گاه معلمان، متخصصان، و دانش آموزان بوده اسـت. نتايج تحليل دادهها با اسـتفاده از آزمون تحليل رتبهاى فريدمن نشـان داد كه مهمترين عوامل مؤثر بر دلزدگى تحصسيلى

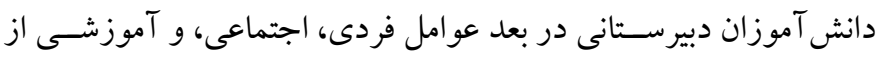


انجام ڤذيرد تا مربى در تدريس و متربى در يادگيرى، احساس رغبت و

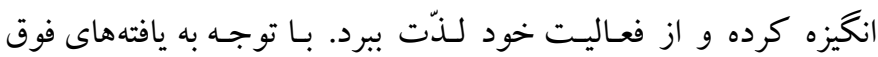

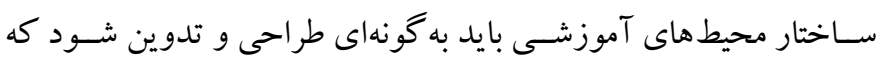
دانش آموزان با تمايل بيشترى به علماندوزى بيردازند.

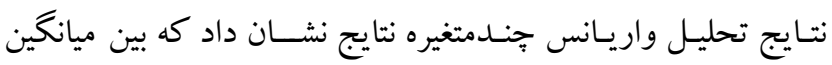

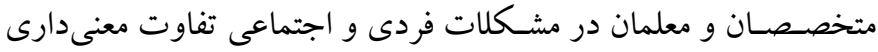

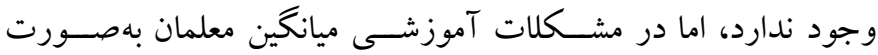

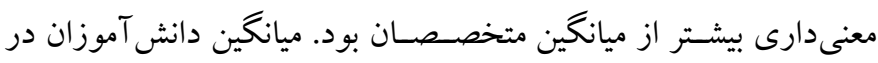

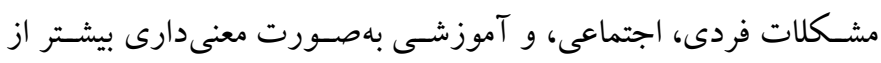

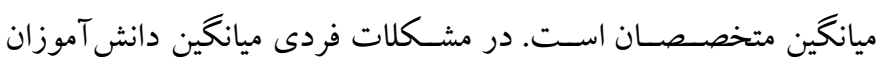
بهصـورت معنىدارى بيشـتر از ميانكين معلمان بود، اما در مشـكلات

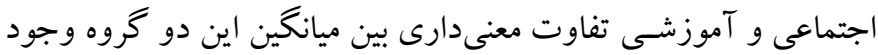

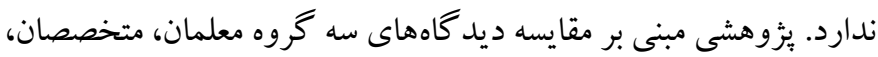

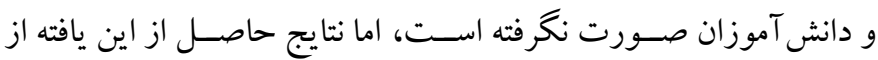

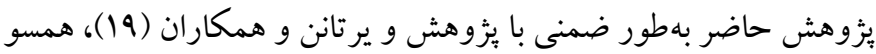

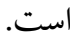

در تبيين يافتهاى حاصل از باسخ اين سؤ ال يُزوهش مى توان كفت،

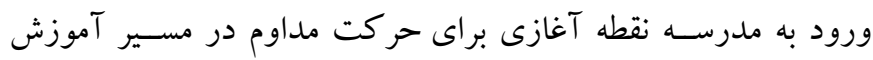
اسـت. نظام آموزشى موظف اسـت با يرورش سـرمايه انسـانى غنى در

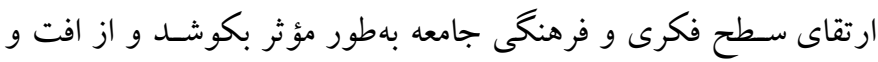
تضسيع شدن امكانات آموزشى جلو گيرى به عمل آورد. مدرسه مكانى

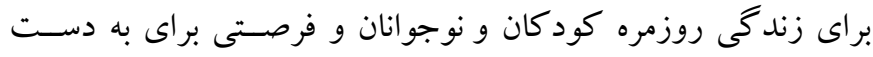

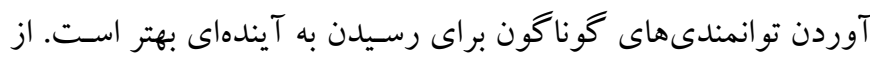

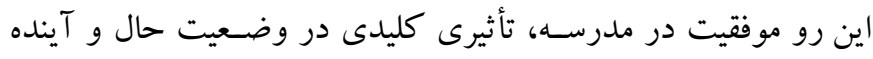

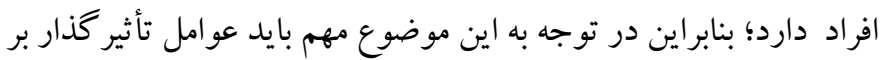

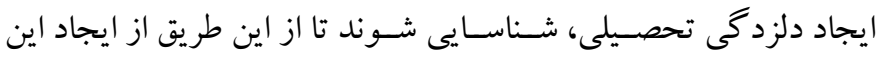
مشكلات در دانش آموزان بيشخيرى به عمل آيد. با توجه به اين يافتها ها و

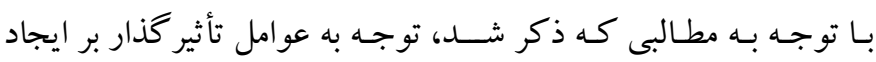

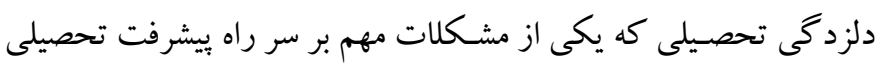

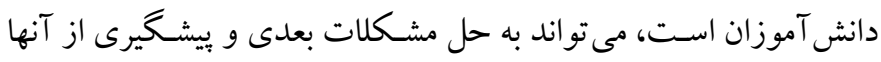
كمك كند. از آنجا كه هر نظام تربيتى به جهت حصول بهترين شر ايط و و

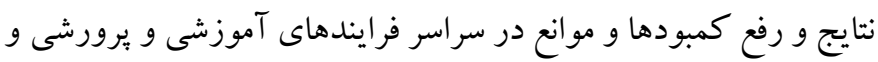

همكاران (·r)، ســالملا-آرو و همكاران (Y)، فريولى و همكاران (19)، ليندون و همكاران (YI)، ايوبى و وِناهى شهر (YI)، و و باسكك و سـالملاآرو (YY)، همسو است. مطابق با بعد مشكلات فردى، عظيمى و همكاران

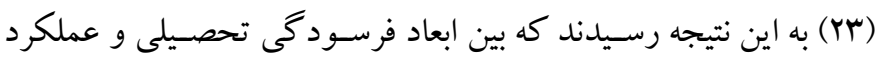
تحصيلى رابطه منفى وجود و بين انخيزش ييشـرفت و عملكرد تحصيلى رسي رابطه مثبت و معنى دارى وجود دارد. آيياى (YF) در بثزوهشسى به اين

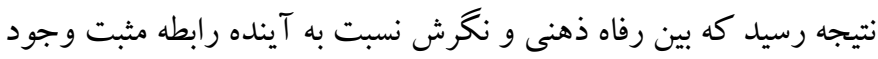

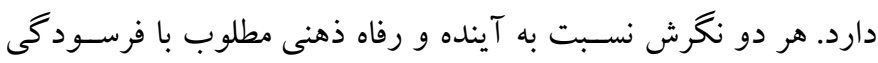
تحصيلى در دانش آموزان دبيرستانى رابطه منفى داشتند.

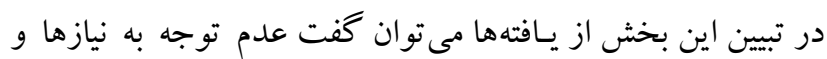

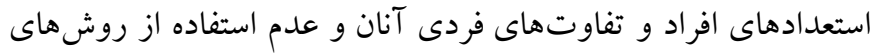
مطلوب تدريس و يادگيرى، علاقه و انخيزه آنان را براى آموختن از بين مىبرد و اين عدم علاقه، بازتاب نامطلوبى بر نتايج كار دارد و ميزان

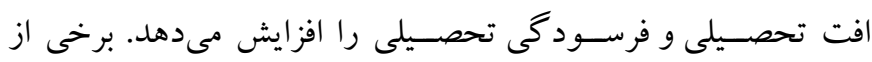

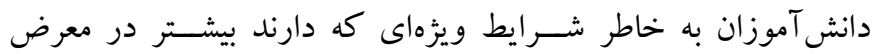

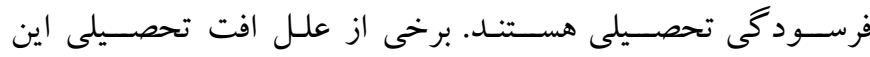

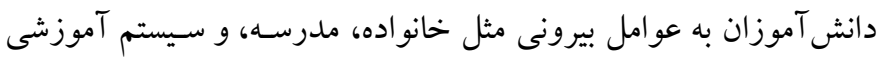

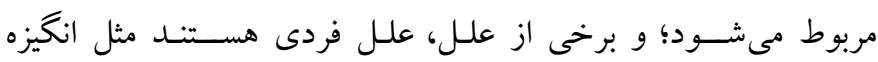

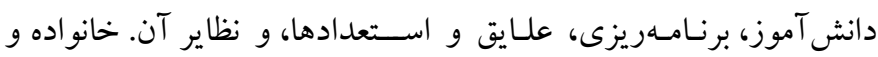

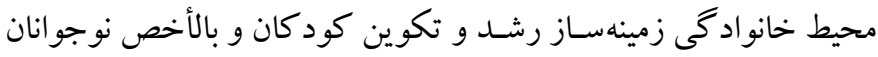
است. دانش آموزانى كه دجار خستخى هيجانى هستند، احساس مى كنند

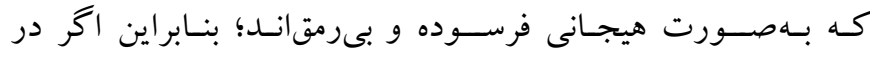
دانش آموزى فرسـود گى تحصسيلى وجود داشــه باشـد، مى توان انتظار داشت كه خستخى تحصيلى نيز در او بالاست (Yه).

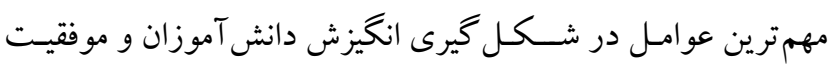
تحصـيلى آنها، خانو اده و مدرســه اسـتـ. مهم ترين نقش والدين ايجاد

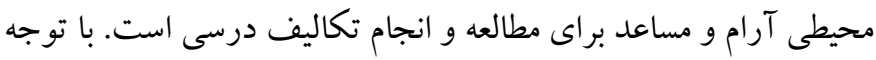

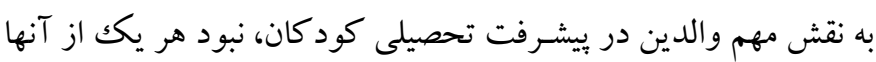
(هردو) به دلايل مختلف تأثير بسيار ناكوارى در تحصيل دانش آموز دارد.

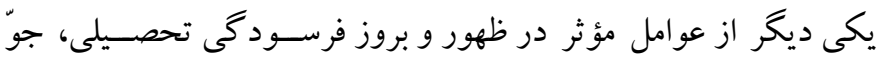

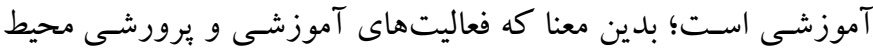
آموزشى بايد در فضـاهاى مناسـب و بر اساس نيازها و علايق فراكيران 
برنامهريزى آموزشى از نتايج مطالعه حاضر و ديخر مطالعات مشابه جهت رفع بىانگيز گى تحصسيلى دانش آموزان اقدام كنند و بهصسورت هدفمند مسير يابى صحيح دانش آموزان را در زمينه تحصيلى، تسهيل كنئد دوران

تشـكر و قدردانى: اين يثزوهش بركرفته از بايانانامه كارشـناسى ارشـد خانم

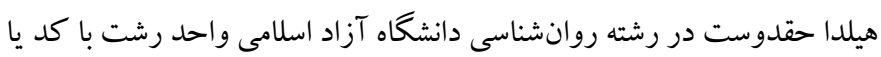

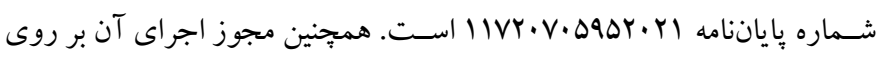

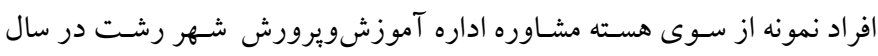

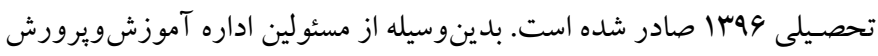

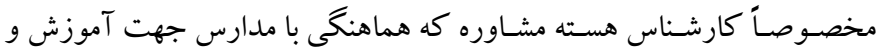
يُزوهش را انجام دادند و همجنين از كادر ادارى و مرييان مدارس و افراد نمونه كه در اجراى اين طرح به ما كمك كردند، تشكر و قدردانى مى مشود. تضاد منافع: هيج گُونه تضاد منافعى براى نويسند گان اين مقاله وجود ندارد.
اسـتفــاده بهينه از امكانات بايد به نتايج يثوهش ها و مطالعات مناسـبـ، اهميـت زيـادى دهـد؛ لـذا انجام يزٔوهشهايى در زمينه بهبود مشــكلات

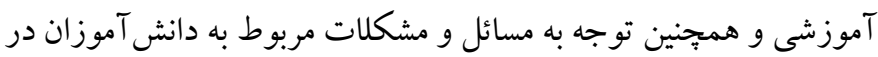

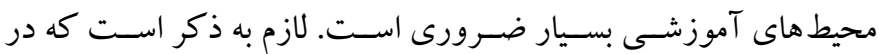
تعميم دهى نتايج مطالعه حاضسر بايد به محدوديتهاى روش شـناختى آن نيز توجه اساسى داشت. از محدوديتهاى اين مطالعه مىتوان به مشكلات

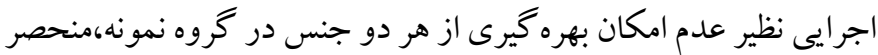

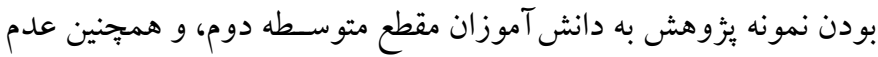

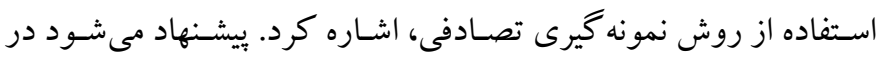

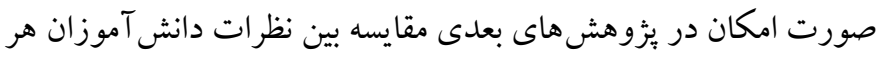
دو جنس، و انجام يزوهش حاضر روى ديخر مقاطع تحصيلى مورد توجه ئه

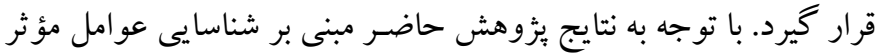

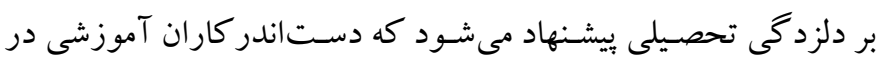




\section{References}

1. Porzoor P, Babaei F, Abbasi M, Pirani Z, Mikaeili A. The effectiveness of mindfulness training with an Islamic approach to disenchantment with school education and student school welfare of students. Jour of Res in Teach 2017; 4(5): 1-16. [Link]

2. Wang J, Liu RD, Ding Y, Xu L, Liu Y, Zhen R. Teacher's Autonomy Support and Engagement in Math: Multiple Mediating Roles of Self-efficacy, Intrinsic Value, and Boredom. Frontiers in psychology 2017; 8: 1006. [Link]

3. Ghadampour E, Farhadi A, Naghibeiranvand F. The Relationship among academic burnout, academic engagement and performance of students of Lorestan University of medical sciences. Research in Medical Education. 2016; 8(2): 60-68.

4. Vogel-Walcutt JJ, Fiorella L, Carper T, Schatz S. The definition, assessment, and mitigation of state boredom within educational settings: A comprehensive review. Educational Psy Rev 2012; 24(1): 89-111. [Link]

5. Gerstner S, Bogner FX. How Science Classroom Teaching Styles May Influence Interest Scores of Different Boredom Types. J Educ Res 2017; 4(2):335. [Link]

6. Macklem GL. Boredom in the classroom: Addressing student motivation, self-regulation, and engagement in learning. Springer; 2015. [Link]

7. Tuominen-Soini H, Salmela-Aro K. Schoolwork engagement and burnout among Finnish high school students and young adults: Profiles, progressions, and educational outcomes. Developmental psychology 2014; 50(3):649. [Link]

8. Kristanto T, Chen WS, Thoo YY. Academic burnout and eating disorder among students in Monash University Malaysia. Eating behaviors. 2016; 22: 96100. [Link]

9. Li Y, Lerner JV, Lerner RM. Personal and ecological assets and academic competence in early adolescence: The mediating role of school engagement. Journal of youth and adolescence 2010; 39(7): 801-15. [Link]

10. Wang MT, Degol J. Staying engaged: Knowledge and research needs in student engagement. Child Development Perspectives 2014; 8(3): 137-43. [Link]

11. Wang MT, Fredricks JA. The reciprocal links between school engagement, youth problem behaviors, and school dropout during adolescence. Child development. 2014; 85(2):722-37. [Link]

12. Wang MT, Chow A, Hofkens T, Salmela-Aro K. The trajectories of student emotional engagement and school burnout with academic and psychological development: Findings from Finnish adolescents. Learning and Instruction 2015; 36:57-65. [Link]

13. Lyndon MP, Henning MA, Alyami H, Krishna S, Zeng I, Yu TC, Hill AG. Burnout, quality of life, motivation, and academic achievement among medical students: A person-oriented approach. Perspectives on medical education 2017; 6(2):108-14. [Link]

14. Salanova M, Schaufeli W, Martínez I, Breso E. How obstacles and facilitators predict academic performance: The mediating role of study burnout and engagement. Anxiety, Stress \& Coping 2010 ;23(1):53-70. [Link]

15. Qinyi T, Jiali Y. An analysis of the reasons on learning burnout of junior high school students from the perspective of cultural capital theory: a case study of Mengzhe Town in Xishuangbanna, China. Procedia-Social and Behavioral Sciences 2012; 46:3727-31. [Link]

16. Fiorilli C, De Stasio S, Di Chiacchio C, Pepe A, Salmela-Aro K. School burnout, depressive symptoms and engagement: Their combined effect on student achievement. Int J Educ Res 2017; 84:1-2. [Link]

17. Kunos N. School Related Burnout and Students' Coping Strategies. European educational research association, ECER Conference 2017. 08-21. [Link]

18. Sharifshad F, Arsang SH, Kheyrollahi F. The Prevalence of Academic Burnout and Some Related Factors in Qom Medical Students. Journal of Qom University of Medical Sciences 2017; 11(2): 77-86. [Link]

19. Virtanen TE, Kiuru N, Lerkkanen MK, Poikkeus AM, Kuorelahti M. Assessment of student engagement among junior high school students and associations with self-esteem, burnout, and academic achievement. Journal for Educational Research Online/Journal für BildungsforschungOnline 2016; 8(2):136-57. [Link]

20. Chang E, Lee A, Byeon E, Lee SM. Role of motivation in the relation between perfectionism and academic burnout in Korean students. Personality and Individual Differences. 2015; 82:221-6. [Link]

21. Ayoobi M, Panahishahri M. The relationship between teaching style of teachers with academic burnout, academic self-efficacy and academic achievement of elementary school students. Third World Conference on Psychology and Educational Sciences, Law and Social Sciences at the Beginning of the Third Millennium, Shiraz 2016. [Link]

22. Bask M, Salmela-Aro K. Burned out to drop out: Exploring the relationship between school burnout 
and school dropout. European journal of psychology of education 2013; 28(2):511-28. [Link]

23. Azimi T, Piri M, Zavvar A. Relationship between academic burnout and achievement motivation with academic performance of high school students. Training and Evaluation 2014; 27: 87-98. [Link]

24. Aypay A. A Positive Model for Reducing and Preventing School Burnout in High School Students.
Educational Sciences: Theory and Practice 2017; 17(4):1345-59. [Link]

25. Yaghoobi A, Bakhtiari M. Effect of Resiliency Education on Academic Exhaustion among Female Students. Research in school and virtual learning 2016; 4 (13): 7-16. 